\title{
THE USE OF LANGUAGE OF PEACE IN SOCIAL MEDIA AS A WAY TO PROMOTE A PEACEFUL LIFE
}

\author{
Sri Wahyuningsih \\ STAIN KUDUS \\ wahyuningsih@stainkudus.ac.id
}

\begin{abstract}
This paper explores the importance of using language of peace in a social media and its effects to promote the peaceful life. Nowadays, the effects of language are undeniably extraordinary both for preserving or damaging a peace. In fact, language is often taken for granted that leads to the problems from a linguistic perspective. One of these problems occurs in a social media in which the language users tend to show impolite languages or insinuation and ignore the readers. Further, they use words that may be accompanied by gestures, yelling, pictures, screaming, etc. As a result, it will lead to chaos, conflict, verbal and physical violence and possibly death. Considering this, the language users both the writers or speakers should be responsible for choosing the words and using acts of discourse that could mitigate the conflicts. In addition, they should be aware of the language use, pragmatic and sociolinguistic in a social practice to promote the peaceful life.
\end{abstract}

Keywords: Language, Social Media, Conflict, Peaceful life

\section{Introduction}

Today, creating a peace requires more active investments, good leaderships, powerful educational values and a productive media world. Humans have rights to respect for others. Furthers, humans are from different area, culture and backgrounds. Regarding this, moral is essentially needed to create respects that lead to a peace. In facts, nowadays, there has been a phenomenon of language accompanied by gestures, yelling, pictures, screaming that will lead to chaos, conflict, verbal and physical violence and possibly death. The language and statements were strengthened by a media which has main roles to socialize and convey the message or communication rapidly. That is why the language users should be responsible for choosing the words and using acts of discourse that could mitigate the conflicts. In addition, they should be aware of the language use, pragmatic and sociolinguistic in a social practice to promote the peaceful life. Otherwise, the conflicts, chaos, and violence will occur among them. As described by the facts occurred in Indonesia several months ago, exactly statements uttered by Saut Situmorang, the vice KPK triggering an anger, demonstration and criticism among the alumni of Islamic Student Associations (HMI). These statements are as follows:

"Saya selalu bilang kalau di HMI minimal dia LK 1 - iyakan, lulus tuh anak-anak mahasiswa, pinter, tapi begitu menjadi menjabat dia jadi jahat, curang, lidih. Ini karena apa? Karena saya bilang sistem belum jalan. Artinya apa? Adapun aturan-aturan itu tidak pernah kita jalankan, ini artinya kenapa karakter dan integritas orang itu berubah. Ini persoalan bangsa kita. Itu yang saya bilang peradaban bangsa kita ini karena apa? Karena memang kita tidak mau bermain dari sesuatu yang terkecil". https://www.nahimunkar.com/ucapan-wakil-ketua-kpk-sautsitumorang-buat-marah-kader-hmi/ 
Those statements above tend to generalize the alumni of Islamic Student Associations (HMI) were bad and cruel. It was an intention and character assassinations of HMI massively. As a result, a number of HMI alumni criticized got furious and demonstrated to against Saut Situmorang in front of his office. Considering this, as a public official, Saut should balance in providing an assessment of anything, included HMI. Further, he should consider the achievements and ideas created by the leaders of HMI for the nation. Using the term of HMI published in a social media as a reference to corrupt behaviors specifically was problematic. Based on this problem, we may have the assumptions that Saut Situmorang as a language user was less aware of the norms of language use including norms of interaction, norms of interpretation, pragmatic and sociolinguistic in a social practice that become crucial aspects in communication.

\section{Language of Peace}

Language is one of the most special blessings to us. For the individual, a language allows people to express themselves. Thus, the communication process and its moral ramifications belong to the importance of language. By a language, people are able to communicate their aesthetic feelings, philosophies, moral, social and religious, cultural and their views and values to others and vice versa. Therefore, the acquisitions of language of use are the basic requirements for people's survival as specie. Regarding this, it is a known fact that language could be a tool to unite people in a nation because the national unity is strengthened when people hear and understand themselves. Conversely, if they do not understand and respect to each other, the national unity will get lost. It is in line with Damboama (2010), advocating that Language is the key to the heart of the people and if such a key is lost, the people are lost as well. On the other hand, when we treasure the key and secure it, it unlocks the door to untold riches. Thus, the language embodies one's culture, values and future. Therefore, it can be deduced that the role of language is crucially needed in interaction and communication. The effects of language are also undeniably extraordinary both for preserving or damaging a peace. If language users are not aware of the aspects of language such as, pragmatic, sociolinguistic in interaction, the language they used will cause chaos, conflicts, and problem and damage a peace. Moreover, if the language is shared in a social media, it will spread out rapidly that enable a group of people knew and get it. In line with it, the language users should adopt and use the language which is based on the language use to avoid conflict and promote a peaceful life among the community.

\section{Message in Public Communication}

Message in communication gives the information conveyed by a communicator. It also gives meanings to people who interpret it. Further, message in public communication can be an instrument to persuade people to be involved in an activity. The persuasive communication does not depend on the power of communicator, but also to the content of message to persuade others. According to Aristoteles in Subiakto and Ida (2012), there are three basic elements in communication including communicative ideology which refers to the revelation of values and ideology conveyed by the communicator, emotional quality which refers to the emotional feeling possessed by people when doing communication, and the person who conveyed meaningful communication or core argument. In line with it, it can be deduced that message in communication has a power to convey values, willingness, ideology, opinions of the communication participants especially persuasive communication to persuade others to behave as the communicator wants. Referring to this, the statements of Saut Situmorang in a social media has a meaningful power that leads to generalize that alumni of HMI were bad and they have potential to do corruption in Indonesia. Certainly, people or the members of HMI who read it will react and criticize Saut's statements by considering a number of reasons. First, people who conveyed the statement is the vice KPK in Indonesia, a man having a relatively high position and power. Secondly, the emotional quality possessed by the people involved, in this case the alumni and the members of HMI. Thirdly, the statements of Saut Situmorang have a deep meaning to the worst action that is corruption. 


\section{P olitician's Hyperbola Language}

Politician used language as an instrument to convey ideas and programs. The language was used by them to enrich several jargons in politics and new meanings of the words. In political communication, politician and language have intense significances. People receiving the message will not only focus on things or materials but also they will focus on who is talking. With regard to the case of Saut Situmorang, his position is as a politician especially the vice KPK will have a strong power when he conveyed the message by using hyperbola language. It is in line with Lindsay Tanner's statement (2007) in Subiakto and Ida (2012), in politics everyone exaggerates about everything all the time. Considering this, it is paramount for politicians to understand and use language carefully. There are several challenges for politicians when they convey the message in social media. If they use simple or usual language, it will not have a significant effect to ensure and influence the others. On the other hand, if they want to show themselves as a true leader, the challenge is how to select and use language correctly at the right time to convince people.

\section{The Role of Social Media}

Social media and communication are the two things which are interrelated. Both of them have the function to support the social interaction of its users. Communication is the process of delivering or sending messages and information between two individuals or more effectively so that it can be understood easily. Fishpond (2013: 72) asserts that communication can work well if the communicant (the recipient) can read and understand the message. Therefore, communicators (information providers) should use the language effectively and efficiently so that the messages and information can be conveyed easily. To present ideas, messages and information, communicators can use tools or social media. It is because social media is believed as a tool to spread out the message quickly. Social media is one of the technological developments that have a major role in providing convenience for people to communicate and socialize. In this context, the role of social media as a communication medium can be used to develop relationships and social interactions that are already built and can be used to get new friends. The users of social media freely communicate, interact, send messages, share and build networking. There are several social media that can be used by the users. They include:

\section{a. Facebook}

Facebook is a social tool to help people communicate more efficiently with their friends, family, and those who are new. It offers easy navigation for users. Lately, facebook becomes very well known for its ability to connect people with a variety of community. Social network Facebook was developed by a Harvard University student, Mark Zuckerberg, who officially launched on February 4, 2004 (www. Wikipedia.org). In Indonesia, the number of Facebook users registered in January 2010 as many as 15,301,280 people (http://tekno. kompas.com).

\section{b. Twitter}

Twitter is a website owned and operated by Twitter Inc., which offers a form of microblogging social network allowing the users to send and read messages called tweets (www. wikipedia.org). Twitter users can send and receive tweets via the Twitter website, compatible external applications (mobile phone), or with a short message (SMS) available in certain countries. 
c. Youtube

Youtube is a video sharing website created by three former PayPal employees in February 2005. The site allows users to upload, watch and share videos. The company is headquartered in San Bruno, California, and embraced the Adobe Flash Video and HTML5 to display a wide variety of user-generated video content, including movie clips, TV clips, and music videos. In addition there are amateur content such as video blogging, short original videos, and educational videos (https://id.wikipedia.org/wiki/YouTube)

\section{d. Blog}

Matheson (2004) describes the blog as a medium of online journal that can be modified continually by the user with their own language and desire. In this context, users can add images or audio files to create a blog look more attractive.

\section{The Awareness of Pragmatic and Sociolinguistic}

Using language cannot be separated from the role of pragmatic and sociolinguistic. O'Keeffe et al (2011) describe the term pragmatics is often used in linguistic research to refer to the study of the interpretation of meaning. Further, Fasold (1990) in O'Keeffe, et al (2011) gave a user-friendly definition to pragmatics; it is the study of the use of context to make inferences about meaning. In this definition, inferences refer to deductions made by participants based on available. Cutting (2008) in O'Keeffe, et al (2011) distinguishes between three different types of spoken context: situational, what speakers know about what they can see around them; background knowledge, what they know about each other (interpersonal knowledge) and the world (cultural knowledge); and co-textual, what they know about what they have been saying.

From the definitions above, it can be deduced that the pragmatic choices made by conversational participants can simultaneously encode indications of position and time and interpersonal and cultural indicators such as power, status, gender and age. Thus, pragmatics provides 'a theoretical framework that can account for the relationship between the cultural setting, the language user, the linguistic choices the user makes, and the factors that underlie those choices'. On the other hand, if language users are competent in using language, meaning that they consider pragmatics, they will be able to create the meaningful statements that lead to avoid conflict and chaos and promote a peace.

In pragmatics, people need to acknowledge the principles of pragmatic. Grice in Mey (1993) describes the principles of pragmatic which include the cooperative principle. This cooperative principle consists of four sub-principles, or 'maxim', to wit.

\section{a. The maxim of quantity}

The rules of the maxim of quantity are language users should make their contribution asinformative as required and they should not make their contribution more informative than required.

\section{b. The maxim of quality}

The rules of this maxim of quality are people should not say what they believe to be false and they should not say that for which they lack adequate evidence.

\section{c. The maxim of relation}


In this rule, people should make their contribution relevant.

\section{d. The maxim of manner}

The rules of the maxim of manners are people should be perspicuous and specifically: avoid obscurity, avoid ambiguity, be brief and be orderly.

In accordance with the maxims above, the aspect of politeness is also important to pragmatics. According to Leech in Mey (1993), the point of politeness, as a principle, is to minimize the effects of impolite statements or expression (negative politeness) and to maximize the politeness of polite illocutions (positive politeness); all the time, of course, bearing in mind the intentions that accompany all conversation. For a clear description, let's have a note the following examples:

Parent: Someone's eaten the icing off the cake.

Child: It wasn't me.

From the example above, it shows that the parent's particular way of insinuating a possible misdemeanor committed by the child is considered to be more polite than a direct accusation. It will be different if the parent had said something like:

Parent: You have eaten the icing off the cake.

Considering the statement above, the child would have been insulted, especially if the accusation in fact was incorrect. Thus, the parent's utterance, while violating the maxim of quantity under the cooperative principle, inasmuch as it is not as informative as possible, or maybe not even relevant at all, obeys the principle of politeness, or thus rescues the Cooperative Principle 'from serious trouble' as Leech remarks.

Referring to the principle of politeness, it may seem that the case of the statement of vice KPK, Saut Situmorang, in a social media several months ago had lack of the principle of politeness. As a result, it caused chaos, conflict and violence among the society. That is why the language users especially a politician should consider the cooperative principles such as maxim of quantity, maxim of quality, maxim of relation and maxim of manner.

Besides pragmatics, language users need to consider sociolinguistics. According to Wardhaugh (2006), sociolinguistic refers to the study of the relationship between language and society; it focuses on how language is used by the individual speaker and groups of speakers in its social context. From this definition, it can be assumed that when using language, people should consider a society around them. A society is a group of people lived together for a certain purpose or purposes. Somehow, a society may be plurilingual that is a number of speakers may use more than one language, however we define language. Wardhaugh (2006) asserts that the definitions of language and society are not independent: the definition of language includes in it a reference to society. Knowledge of Language When two or more people communicate with each other in speech, we can call the system of communication that they employ a code. In most cases that code will be something we may also want to call a language. Moreover, people should also be aware that two speakers who are bilingual, that is, who have access to two codes, and who for one reason or another shift back and forth between the two languages as they converse by codeswitching are actually using a third code, one which draws on those two languages. In social practice, we may not forget to the importance of grammars because the knowledge that everyone has of the language he or she speaks is quite hard to describe. Moreover, we may not ignore the importance of the social context of language use. According to Mey (1993), such a context naturally presupposes the existence of a particular society, which its implicit and explicit values, 
norms, rules and laws and with all its particulars conditions of life: economic, social, political and cultural. All these factors together are often referred to by a metaphorical expression: "the fabric of society".

\section{The Role of language for Peace to Promote a Peaceful Life}

Islam calls on all mankind to know each other, because they all come from one grandparent ancestor. Islam regards all human beings as one family. In fact, Islam makes the goal of creation humans is that they know each other and live together. The teachings of the Kor'an lead us to the peace. Allah SWT said, "It has come unto the light of God and the book that explains. With that book, Allah gives guidance to those who follow His good pleasure to the road of full safety; removing them from darkness into the light by His leave; and give them clues to the straight path. "(Q.s. Al-Maidah: 15-16).

From the verse above, it can be deduced that Islam also gives the teachings to create a peaceful life that can be achieved by using the language for peace. The role of language for a peace can be appreciated when people recognize that language becomes an integral part of people's culture and as a medium of interaction and ways of expressing thoughts and feelings in a society. It is strengthened by Cohen (2010) in Ani (2015) gave more light on this assertion when he states that communal life is possible only because members of a community posses a set of shared meanings which enables them to make coherent sense of the world. It is in line with Seweje (2005) in Ani (2015) commenting on the role of language as peace, war and conflict resolution stated that language can cause war and breed peace.

Further, she remarked that having too many languages and diverse dialects within a nation can affect mutual co-existence and understanding and this may lead to conflict. Having considered a variety of conflicts, we should look the solutions peacefully to resolve it. One of the solutions is the use of effective stylistic approach to address a contending issue. This solution is also sharpened by Cohen (2001) stressing that in interconnected chain of non-verbal and verbal messages, conciliation can advance only when there is synchronized and consecutive understanding at every stage of the process. People should maintain the information and message comprehensibly and the parties must be able to draw a shared store of meaning. On the other hand, in some societies, possibly equivalent words have variations or differences in meaning and when these variations in meaning are not explained in an understandable term to other people, there will be conflict based on the wrong perceptions on the meaning of the word. In addition, the cultural gaps between the ways of life of society will lead to the potential semantic gap between concepts and their labels across languages. That is why the equivalent concept in language is needed to have same meanings. What people expect of reconciliation will be determined by the local knowledge that informs their understanding of the term.

In line with Cohen (2011), Jija (2012) emphasized that language should be carefully, responsibly and politely used so as to advance individual and group co-operation in social affair. From this statement, it can be referred that the effective communication of skills are necessary pre-requisite in suppressing conflicts. Referring to Jija's statement, it is clear that words which are considered as being segregate and divisible linguistically should be changed by the more accommodating and unity enhancing the words. Further, the inflammatory language or wrong and misconceived words should not be used when referring to our relationship. Consequently, the best way for achieving peace and resolving conflict is the use of languages that honors and respects human dignity, tolerance, truth and national integration.

Besides the use of language of peace, there are a variety of ways to promote a peaceful life. According to UNESCO (2013), there are several ways to achieve a peace. These ways include:

\section{a. Recognition of and respect for knowledge}


including traditional and indigenous knowledge - which contributes to safeguarding biodiversity and to promoting sustainable development. Pilot projects highlighting the place of science in the process of dialogue as a universal language are envisaged. For instance, activities underlying the importance of the history of science in raising awareness on the role of science for the rapprochement of cultures and its significance in helping to understand the close interconnection of science with the growth of civilization and the flourishing of cultures. The history of science and scientific thought should be regarded as an instrument for the new humanism which is celebrated every year on the occasion of the World Science Day for Peace and Development (November 10).

b. Development of an interactive educational program to stop violence in schools.

Using the UNESCO Associated School-Network (ASPnet) as an outreach tool, develop a model interactive educational programme for adaptation and implementation at local/ community levels to stop violence and involving schools, including students and teachers, parents, the media and professional bodies. Students are the main actors in this exercise. Through interviews, testimonies, etc., they document on their own the problems inside/ outside schools and possible solutions in working with parents, the media, police, municipal education boards, municipal administrators and councilors through online platforms and school-based activities.

c. Learning from the past: promoting dialogue for reconciliation and intercultural understanding.

Building on the experience of the on-going Transatlantic Slave Trade Education project and the Slave Route: Resistance, Liberty Legacy project, this activity continues to provide opportunities for networking and exchange to increase awareness and deepen knowledge about the causes, modalities and consequences of the Slave Trade and Slavery in order to work towards a future free from racism, discrimination and intolerance. A specific focus is given to increase interregional student and teacher exchanges via ICTs. As a consequence, peace should be more and more recognized as the cornerstone of all people's daily lives both in terms of prevention and reconciliation, particularly in contexts characterized by social and economic unrest, ethnic or religious hostility, post-conflict situations, contested electoral processes, and other forms of violence-prone environments. Addressing those situations through activities at the global, regional, national and local levels, a culture of peace has the potential to result in everyday peace, a peace crafted by all members of societies.

\section{d. Encourages internal reflexivity}

as a space to perceive the possible gaps or deficits in one's own cultural system. Indeed cultural diversity must incorporate a certain degree of epistemological multi perspectivity, that is, recognition that there are other legitimate ways to see the world than one's own.

e. Strengthens the capacity for living together in conviviality.

This capacity cannot be taken for granted; it must be consciously encouraged and nurtured. To be convivial requires the willingness to build partially shared social worlds - of work, politics, leisure and information - with people who may not share the same cherished cultural assumptions. This is an elementary requirement for practical, daily cultural pluralism.

\section{f. Supports willingness to change one's cultural horizons}

engage in creative adaptation and anticipation, which are also not to be taken for granted. Where there is openness to creative transformation within a cultural system, possibilities 
for new ways of learning and living together can emerge.

\section{Conclusions}

The role of language is paramount for human's existence. It is a means of communications and social activities. Nowadays, people used a social media as in instruments to express language, ideas and messages. Thus, the effects of language are undeniably extraordinary both for preserving or damaging a peace. One of these problems occurs in a social media in which the language users tend to show impolite languages or insinuation and ignore the readers. As a consequence, this will lead to chaos, conflict, violence and hostility. In accordance with this, the language users should be aware of the language use, pragmatic and sociolinguistic in a social practice to promote the peaceful life. Further, there is need for us to use language appropriately in a social media so that it fosters common sense of identity, integration and creates unity in diversity.

\section{References}

Al-Qur'an, (Al-Maidah: 15-16).

Ani, Calius Odo. (2015).The role of language for peace and Conflict Resolution. Journal of Research Development, Volume 24 No.2.

Cohen, R. (2001). Language and conflict resolution: The limit of English. International studies review 3 (1) p $28-57$.

Damboama, Ruth D. (2010). Language Education as An instrument of Peace, unity, and Stability in Nigeria. Journal of Assertiveness

Facebook. Accessed on June 20, 2016, from: (http://tekno.kompas.com).

Jija, T. (2012). Language as a tool for conflict management and resolution. Journal of Igbo language and linguistics 5.

Matheson, D. (2004). Weblogs and the epistemology of the news: Some trends in online journalism. New Media \& Society, 6 (4), 443-468

Mey, L. Jacob. (1993). Pragmatics an Introduction. Cambridge: Blackwell.

O'Keeffe, et al. (2011). Introducing pragmatics in use, London: Routledge

Subiakto, Henry and Ida, Rachmah. (2012). Komunikasi Politik, Media dan Demokrasi, Jakarta: Prenada Media Group

UNESCO'S Programme of Action Culture of Peace and Non-Violence: A vision in Action. Paris: Unesco.

Wakil Ketua KPK Saut Situmorang buat marah, accessed on June 20, 2016 in: https://www. nahimunkar.com/ucapan-wakil-ketua-kpk-saut-situmorang-buat-marah-kader-hmi/

Wardhaugh, Ronald. (2006). an Introduction to Sociolinguistics, Fifth Edition, Malden: Blackwell.

YouTube, Accessed on June 20, 2016, from: (https://id.wikipedia.org/wiki/YouTube) 